\title{
Organics and Micronutrient Management Practices on Soil Available Nutrient and Yield of Aerobic Rice
}

\author{
B. Sagarika, Y. Ashoka Reddy* and V. Sumathi \\ Department of Agronomy, S.V. Agricultural College, Tirupati - 517 502, A.P., India \\ *Corresponding author
}

\begin{abstract}
A B S T R A C T
Keywords

Aerobic rice, Organics and Micronutrients.

Article Info

Accepted:

10 September 2017

Available Online:

10 November 2017

This investigation was conducted at S.V. Agricultural College, Tirupati, to evaluate the performance of aerobic rice under organics and micronutrients. The experiment was consisted of three organic practices in main plot viz., FYM (farm yard manure), GLM (green leaf manure) and no organics and seven micronutrient management practices in subplots i.e., application of iron and zinc either alone or in combination to the soil or foliage and laid out in slit plot design and replicated thrice with Sravani (NLR-33359) variety. As regards the organics, significantly higher post-harvest soil available N, P, K, Fe and $\mathrm{Zn}$ content and yield was noticed with the incorporation of FYM. Among the micronutrient management practices, Foliar application of $0.25 \% \mathrm{FeSO}_{4}$ and $0.5 \% \mathrm{ZnSO}_{4}$ twice at 20 and 30 DAS has recorded maximum value of post-harvest soil available N, P, $\mathrm{K}, \mathrm{Fe}$ and $\mathrm{Zn}$ content and higher yield compared to rest of the micronutrient management practices tried.
\end{abstract}

\section{Introduction}

Rice (Oryza sativa L.) is the staple food of more than a half of the World population (Ginigaddara and Ranamukhaarachchi, 2009). Rice is grown in as much as 114 countries across the world, in an area of $150 \mathrm{M}$ ha, which constitute nearly 11 per cent of the world's cultivated land. More than 90 per cent of the world's rice is produced and consumed in Asia, which is the livelihood for 60 per cent of earth's population (Mangala Rai, 2007). Geometric growth of population and arithmetic increase in food grain production leave a vast gap in food supply. This gap is further widened due to urbanization and industrialization of fertile lands. The agricultural growth rate has slowed down to 2 $\%$ during 2008-09 in India (GOI, 2010) and increased agricultural productivity is needed to meet the increasing needs of the growing population. In India, rice researchers are currently testing the growing of popular low land rice varieties under aerobic conditions and found that among the constraints in aerobic rice culture, one of the yield reducing factors was the micronutrient deficiencies. Among the micronutrients, zinc is now regarded as the third most limiting nutrient element in crop production after $\mathrm{N}$ and $\mathrm{P}$ (Gupta, 1995) and the extent of iron deficiency in India is next to that of zinc (Neue and Lantin, 1994).

The nutrient deficiencies have appeared after the introduction of aerobic system of rice 
cultivation due to changes in the physical, chemical and biological properties of the soil. In aerobic situation the available ferrous form of iron is converted to unavailable ferric form thereby making it unavailable, due to absence of reduced zone. Further, in aerobic situation, limited use of organics and absence of proper recycling of crop residues has also aggravated the deficiency symptoms of major micronutrients. Thus, to achieve a higher yield and also to overcome micronutrient deficiencies especially in case of zinc and iron, optimum dose and proper method of application of these micronutrients become most relevant in aerobic rice system. Therefore, the common micronutrient deficiency of aerobic rice envisages that it has become imperative to give due consideration for organics usage along with micronutrients.

\section{Materials and Methods}

A field experiment was conducted during rabi, 2010-11 at S.V. Agricultural College Wetland Farm, Tirupati Campus, Acharya N.G. Ranga Agricultural University, Andhra Pradesh. The soil of the experimental site was sandy clay loam in texture having $\mathrm{pH} 7.7$, low in organic carbon and nitrogen content, high in phosphorus and potassium and medium in iron and zinc. The experiment was laid out in a split plot design and replicated thrice. The treatments consisted of three main plot organic practices viz., $\mathrm{M}_{1}$-farm yard manure @ $10 \mathrm{t} \mathrm{ha}^{-1}, \mathrm{M}_{2^{-}}$green leaf manure through Glyricidia maculata @ $5 \mathrm{t} \mathrm{ha}^{-1}, \mathrm{M}_{3^{-}}$no organics and seven sub plot micronutrient management practices viz., $\mathrm{S}_{1}$-soil application of $\mathrm{FeSO}_{4} @ 25 \mathrm{~kg} \mathrm{ha}^{-1}$ as basal, $\mathrm{S}_{2}$-soil application of $\mathrm{ZnSO}_{4} @ 25 \mathrm{~kg} \mathrm{ha}^{-1}$ as basal, $\mathrm{S}_{3}$ - soil application of $\mathrm{FeSO}_{4}$ and $\mathrm{ZnSO}_{4} @ 25$ $\mathrm{kg} \mathrm{ha}^{-1}$ each as basal, $\mathrm{S}_{4}$ - foliar application of $0.25 \% \mathrm{FeSO}_{4}$ at 20 and $30 \mathrm{DAS}, \mathrm{S}_{5}$ - foliar application of $0.50 \% \quad \mathrm{ZnSO}_{4}$ at 20 and 30 DAS, $\mathrm{S}_{6^{-}}$foliar application of $0.25 \% \mathrm{FeSO}_{4}$ and $0.50 \% \mathrm{ZnSO}_{4}$ at 20 and $30 \mathrm{DAS}, \mathrm{S}_{7-}$ control (no micronutrient) were allotted to sub plots with Sravani (NLR- 33359) as test variety. Presoaked seeds were used for sowing@2 seeds per hill at 15 X $10 \mathrm{~cm}$ spacing. A uniform dose of 100:0:50 kg N, $\mathrm{P}_{2} \mathrm{O}_{5}$ and $\mathrm{K}_{2} \mathrm{O}$ ha $^{-1}$ were applied to all the plots. All other management practices were adopted for aerobic rice cultivation as per the recommendations of Acharya N.G. Ranga Agricultural University, A.P. Data recorded on various parameters of crop was subjected to statistical scrutiny by the method of analysis of variance as outlined by Panse and Sukhatme (1985).

\section{Results and Discussion}

As regards the organics, significantly higher post-harvest soil available nitrogen content was noticed with the incorporation of FYM. The minimum content of post-harvest soil available nitrogen was recorded without the incorporation of organics. Among the micronutrient management practices, soil application of iron and zinc had recorded maximum value of post-harvest soil available nitrogen compared to rest of the micronutrient management practices tried. The lowest value of soil available nitrogen was associated with non-supply of micronutrients. The higher nitrogen content of soil was due to the improved soil properties, mineralization of native organic nitrogen compounds (Imtilemla et al., 2009).

Significantly, higher soil available phosphorus was resulted from the FYM incorporated plots than those with green leaf manure incorporation. The lowest postharvest soil available phosphorus content was associated with no organics. This is due to the fact that during the mineralization of organic manure, a number of organic acids, especially the hydroxyl ions (product of microbial metabolism) are produced, which released phosphorus through chelation or by removal of metal ions from the insoluble metal phosphates (Mohandas and Appavu, 2000). 
Table.1 Post harvest nutrient status and yield of aerobic rice as influenced by organic and Micronutrient management practices at harvest

\begin{tabular}{|c|c|c|c|c|c|c|c|}
\hline Treatments & $\begin{array}{c}\text { Nitrogen } \\
\left(\mathrm{kg} \mathrm{ha}^{-1}\right)\end{array}$ & $\begin{array}{c}\text { Phosphorus } \\
\left(\mathrm{kg} \mathrm{ha}^{-1}\right)\end{array}$ & $\begin{array}{c}\text { Potassium } \\
\left(\mathrm{kg} \mathrm{ha}^{-1}\right)\end{array}$ & $\begin{array}{c}\text { Iron } \\
\left(\mathrm{mg} \mathrm{kg}^{-1}\right)\end{array}$ & $\begin{array}{c}\text { Zinc } \\
\left(\mathrm{mg} \mathrm{kg}^{-1}\right)\end{array}$ & $\begin{array}{c}\text { Grain yield } \\
\left(\mathrm{kg} \mathrm{ha}^{-1}\right)\end{array}$ & $\begin{array}{c}\text { Straw yield } \\
\left(\mathrm{kg} \mathrm{ha}^{-1}\right)\end{array}$ \\
\hline \multicolumn{8}{|l|}{ Organics } \\
\hline $\mathrm{M}_{1}$ & 198.49 & 41.62 & 169.71 & 23.65 & 2.66 & 2932 & 5779 \\
\hline $\mathrm{M}_{2}$ & 186.59 & 35.33 & 160.60 & 19.52 & 2.29 & 2750 & 5539 \\
\hline $\mathrm{M}_{3}$ & 154.76 & 26.33 & 147.97 & 12.59 & 1.82 & 2310 & 5203 \\
\hline SEm \pm & 2.43 & 0.94 & 1.82 & 0.72 & 0.10 & 24.61 & 22.94 \\
\hline $\mathrm{CD}(\mathrm{P}=0.05 \%)$ & 9.50 & 3.66 & 7.09 & 2.79 & 0.37 & 96 & 90 \\
\hline \multicolumn{8}{|c|}{ Micronutrient management } \\
\hline $\mathrm{S}_{1}$ & 204.11 & 50.29 & 171.47 & 27.26 & 2.47 & 2504 & 5392 \\
\hline $\mathrm{S}_{2}$ & 219.61 & 43.67 & 184.24 & 20.00 & 2.91 & 2673 & 5522 \\
\hline $\mathrm{S}_{3}$ & 236.71 & 59.04 & 195.49 & 25.12 & 2.68 & 2915 & 5749 \\
\hline $\mathrm{S}_{4}$ & 141.38 & 25.53 & 136.37 & 18.55 & 1.87 & 2543 & 5408 \\
\hline $\mathrm{S}_{5}$ & 158.05 & 17.82 & 146.47 & 13.39 & 2.31 & 2704 & 5548 \\
\hline $\mathrm{S}_{6}$ & 175.25 & 34.09 & 157.47 & 15.64 & 2.08 & 2946 & 5774 \\
\hline $\mathrm{S}_{7}$ & 124.54 & 10.52 & 124.47 & 10.16 & 1.46 & 2306 & 5157 \\
\hline SEm \pm & 4.79 & 2.00 & 3.13 & 1.12 & 0.13 & 41.70 & 39.01 \\
\hline $\mathrm{CD}(\mathrm{P}=0.05 \%)$ & 13.74 & 5.75 & 8.98 & 3.21 & 0.38 & 120 & 112 \\
\hline
\end{tabular}


Regarding micronutrient management practices, significantly higher values of soil available phosphorus were noticed with soil application of iron and zinc, which was however, significantly superior to other treatments. The lower soil available phosphorus was registered with non-supply of micronutrients. This might be due to efficient utilization of supplied phosphorus by the crop.

The status of post-harvest soil available potassium was highest with FYM incorporation, while the minimum value was associated without organic incorporation. Among the micronutrient management practices, significantly larger values of post-harvest soil available potassium content was observed with soil application of iron and zinc, while the nonsupply of micronutrients has registered significantly lower values. Dixit and Gupta (2000) observed that application of FYM and Blue Green Algae (BGA) either alone or in combination significantly increased the $\mathrm{N}, \mathrm{P}$ and $\mathrm{K}$ status of soil.

The higher value of post-harvest soil available iron was noticed with the FYM incorporation, which was significantly superior to green leaf manure incorporation and no organics. Significantly lower post- harvest soil available iron was associated with no organic incorporation which might be due to unavailability of iron when soil $\mathrm{pH}$ was more than 7. This may be attributed to the production of natural chelating agents from organic manures that help in keeping Fe soluble form and more available to plants (Sakal, 2001). Application of organics (FYM, green manuring and compost) helps in mobilization of inherent soil iron in available forms during their decomposition (Sarkar, 2003). With respect to micronutrient management practices, significantly higher value of post-harvest soil available iron content was recorded with the soil application of iron alone which was comparable with combined application of iron and zinc while the lower value was recorded with non-supply of micronutrients (Table 1).
The soil status with regard to post harvest available zinc was maximum with incorporation of FYM, while the non-incorporation of FYM or GLM resulted in minimum content of zinc. Incorporation of organic manures in soil is quite effective to mitigate zinc deficiency in crops. Organic manures serve as a source of zinc and also their decomposition products give rise to natural complexing agents which mobilize the native zinc already present in soil through chelation. These results were similar to findings of Sakal (2001). Among the micronutrient management practices, the soil available zinc content was found to be higher with the soil application of zinc either alone or in combination with iron, which was comparable among them. The lower value was observed with the non-supply of micronutrients. The increased availability of zinc in the soil may be ascribed to the chelating action of the organic materials as reported by Devarajan and Krishnasamy (1996). Organic manures have been found to increase the efficiency of soil applied zinc. Zinc use efficiency increases twice with combined application of $10 \mathrm{tha}^{-1}$ either of FYM or compost with 2.5-5 $\mathrm{kg} \mathrm{Zn} \mathrm{ha}^{-1}$ (Sarkar, 2003). The higher post-harvest nutrient status of soil associated with the FYM incorporation followed by green leaf manuring compared to control might be due to the release of acids during their decomposition which would release nutrients in to the soil. Such improvement of soil status has been indicated by Senapati and Senapati (2004).

Incorporation of FYM @ $10 \mathrm{t} \mathrm{ha}^{-1}$ registered significantly grain and straw yield compared to other treatments. This might be ascribed to higher growth parameters along with better translocation of photosynthates to the grains resulted in higher yield. These results were in conformity with the findings of Shekhara et al., (2010). Foliar application of $0.25 \% \mathrm{FeSO}_{4}$ and $0.5 \% \mathrm{ZnSO}_{4}$ twice at 20 and 30 DAS has recorded higher yield which may be due to the adequate availability of macro and micronutrients as they play a major role as catalyst in various growth processes, hormone production and protein synthesis which inturn 
resulted in better translocation of photosynthates to sink (Ramana et al., 2006).

In conclusion, the present study has revealed that incorporation of FYM @ $10 \mathrm{t} \mathrm{ha}^{-1}$ and foliar application of $0.25 \% \mathrm{FeSO}_{4}$ and $0.50 \% \mathrm{ZnSO}_{4}$ at 20 and 30 DAS was the economically sound practice with higher aerobic rice yields.

\section{References}

Devarajan, R and Krishnasamy, R. 1996. Effect of $\mathrm{Zn}$-enriched manures on rice yield. Madras Agricultural Journal, 83(5): 280283.

Dixit, K.G and Gupta, B.R. 2000. Effect of farmyard manure, chemical and biofertilizers on yield and quality of rice (Oryza sativa L.) and soil properties. Journal of Indian Society of Soil Science, 48(4): 773-780.

Ginigaddara, G. A. S. and Ranamukhaarachchi, S. L. 2009. Effect of conventional, SRI and modified water management on growth, yield and water productivity of direct-seeded and transplanted rice in central Thailand. Australian Journal of Crop Science, 3(5): 278-286.

GOI. 2010. Union budget and economic survey. Ministry of Finance, Government of India, New Delhi, India.

Imtilemla, Chauhan, B.S and Manoj Dutta. 2009. Effect of continuous cultivation and nutrient management on available $\mathrm{N}, \mathrm{P}$ and $\mathrm{K}$ content and yield of upland rice (Oryza sativa L.) on terraced land. Indian Agriculturist, 53(1\&2): 61-67.

Mangala Rai. 2007. The cereal that feeds billions. Indian Farming, 56 (1): 4-9.

Mohandas, S. and Appavu, K. 2000. Direct and residual effect of combined application of basic slag with green leaf manures on soil available nutrients and yield of rice. Madras Agricultural Journal, 87(1-3): 5356.

Neue, H.U and Lantin, R.S. 1994. Micronutrient toxicities and deficiencies in rice. In A.R. Yio and T.J. Flowers, (ed.) Soil Mineral Stresses: Approaches to crop improvement. Springer-Verlag, Berlin, Germany.

Panse, V.G and Sukhatme, P.V. (Revised by Shukatme, P.V and Ambe, V.N.). 1985. Statistical Methods for Agricultural Workers. ICAR, New Delhi. pp: 100-174.

Ramana, A. V., Sreenivasulu Reddy, D. and Ramakumar Reddy, K. 2006 Influence of mulching and micronutrient management practices on upland rice Karnataka Journal of Agricultural Sciences, 19(4): 785-788.

Sakal, R.M. 2001. Efficient management of micronutrients for sustainable crop production. Journal of Indian Society of Soil Science, 49(4): 593-608.

Sarkar, A.N. 2003. Conjunctive use of micronutrients-organics for stimulating crop response. Fertilizer News, 48(2): 33$34 \& 37-44$.

Senapati, H.K and Senapati, P.C. 2004. Effects of long-term application of manure and fertilizer on the upland rainfed ricecropping system. International Rice Research Notes, 29(2): 60-61.

Shekara, B. G., Sharanappa and Krishnamurthy, N. 2010. Effect of irrigation schedules on growth and yield of aerobic rice (Oryza sativa) under varied levels of farmyard manure in Cauvery command area. Indian Journal of Agronomy, 55(1): 35-39.

\section{How to cite this article:}

Sagarika, B., Y. Ashoka Reddy and Sumathi, V. 2017. Organics and Micronutrient Management Practices on Soil Available Nutrient and Yield of Aerobic Rice. Int.J.Curr.Microbiol.App.Sci. 6(11): 759-763. doi: https://doi.org/10.20546/ijcmas.2017.611.089 